\title{
Training, Ideas and Practices. The Law of Nations in the Long Eighteenth Century: An Introduction to the Focus Section
}

\author{
Raphaël Cahen \\ Postdoctoral researcher, visiting lecturer, Vrije Universiteit Brussel \\ Raphael.Cahen@vub.be \\ Frederik Dhondt \\ Assistant Professor, Vrije Universiteit Brussel \& Visiting Lecturer, \\ University of Antwerp \\ Frederik.Dhondt@vub.ac.be \\ Elisabetta Fiocchi Malaspina \\ Assistant Professor, University of Zurich \\ elisabetta.fiocchi@rwi.uzh.ch
}

This focus section is the result of the conference Training, Ideas and Practices. The Law of Nations in the Long Eighteenth Century, which took place in Paris on 18-19 May 2017. ${ }^{1}$ The purpose of this conference was to explore the roots of international law and the various concepts related to the 'law of nations' by looking at the legal language of diplomats and foreign offices in Europe during the long eighteenth century (ca.1680-1830). The variety and complexity of specific mechanisms through which the law of nations was applied for diplomatic use were an evident focus, but also social and cultural aspects, and the practical questions that diplomats frequently faced were discussed. ${ }^{2}$

1 The conference has received the generous support of the CIERA (Centre interdisciplinaire d'études et de recherches sur l'Allemagne, www.ciera.fr) as a colloque junior, of the Research Group CORE (VUB), and took place at the Fondation Biermans-Lapôtre: we are grateful to all these Institutions. Special thanks go to Professors Luigi Nuzzo (Università del Salento) and Miloš Vec (Universität Wien/IWM) as keynote speakers of the conference, and to Christine Lebeau (Université Paris I Panthéon-Sorbonne), who participated in a fruitful debate.

2 Drocourt, Nicolas and Éric Schnakenbourg, eds. Thémis en diplomatie: l'argument juridique dans les relations internationales de l'antiquité tardive à la fin du XVIII siècle (Rennes: Presses universitaires de Rennes, 2016). 
The relationship between diplomacy and the law of nations is at best ambiguous. Furthermore, the law of nations seems to be a hybrid product of philosophical concepts and a digest of diplomatic practice. Lawyers have difficulty to resist the temptation to write a purely academic or genealogical history of the law of nations. On the one hand, the frequent invocation by eighteenth century diplomats of authors such as Grotius or Vattel seems to support this. ${ }^{3}$ On the other hand, interaction in negotiations involves a lot more than invoking legal authorities. A thorough analysis of diplomatic practice often reveals implicit rules within diplomacy as a social field. ${ }^{4}$

Legal arguments are part of this microcosm, but geopolitical determinants and state interests can bend and bow the use of legal language. One of the main issues is whether law of nations theories influenced diplomatic practice and at the same time whether diplomatic practice altered traditional law of nations concepts.

This focus section establishes a dialogue between young legal historians, historians of political thought and historians of politics from different parts of Europe. Three different scenarios are envisaged to uncover the emergence of law of nations theories, both in diplomatic practice and doctrine: the training of diplomats, circulation of ideas and diplomatic networks, and the transformation of the law of nations through practice.

The role of ambassadors in the construction of the modern state is still central to much recent scholarship. ${ }^{5}$ The section concerning training of diplomats investigates whether the law of nations was the basis of diplomatic education. Was diplomatic training theoretical or based on practice and experience? The existence and evolution of a form of professionalization of diplomats is at the heart of the following papers, especially in light of the thorough transformation at the end of nineteenth century. ${ }^{6}$

Dante Fedele scrutinizes the role of literature on the ambassador in diplomatic training. Established institutions for diplomatic training were lacking until the end of the eighteenth century (except in the case of oriental diplomacy). The literary genre of diplomatic guides first focuses on ancient history;

3 Haggenmacher, Peter and Vincent Chetail, eds. Vattel's International Law from a XXIst Century Perspective (Leiden/Boston: Martinus Nijhoff/Brill, 2011).

4 Bourdieu, Pierre. Sur l'Etat. Cours au Collège de France (1989-1992) (Paris: Seuil, 2012).

5 See for example Andretta, Stefano, Stéphane Péquignot and Jean-Claude Waquet, eds. De l'ambassadeur et à l'art de négocier du Moyen Âge au début du XIX ${ }^{e}$ siècle (Rome: École française de Rome, 2015), DOI 10.400o/books.efr.2887.

6 See Nuzzo, Luigi and Miloš Vec, eds. Constructing International Law - The Birth of a Discipline (Frankfurt am Main: V. Klostermann, 2012). 
next, experiences and modern history; finally, peace treaties as the 'code de droit public' for European diplomats.

In her article on the Ecole des Jeunes de langues Zülâl Muslu points to the common European diplomatic culture in Ottoman-Western European relations. The dragomans, 'a priori secondary actors', where in fact 'cosmopolite'. They had a tremendous impact on legal practice (e.g. Küçük Kaynarca in 1774) and the Turkish language.

Alice Bairoch de Sainte-Marie confronts French diplomatic theory with its application in America. She highlights the seminal role of the Jesuit order in establishing contact with native Indian tribes. To what extent were the works of Jean Hotman (1603) and Callières (1716) representative of negotiations in an utterly different cultural setting, characterized by oral and symbolical proceedings?

The three final papers treat the transformation of the law of nations through practice. They analyse the formation and transformation of the law of nations, showing the entanglements between international relations, legal discourse and doctrine. Numerous aspects of this complexity are taken into account, namely how diplomatic practice played a central role for the consolidation of legal principles. The frequent reiteration of guarantees in diplomatic practice contributed to their institutionalisation. From this perspective, Patrick Milton investigates the guarantee of German liberties by external guarantors France and Sweden, arguing that the duty of these external forces to uphold the internal German order was the most lasting contribution of the Westphalian Peace Treaties to international law.

However, transformation also means application of the law of nations doctrine and the practical use of Vattel's Le droit des gens. This is illustrated by Elisabetta Fiocchi Malaspina for eighteenth century Italian diplomacy. Le droit des gens was not used exclusively as a political benchmark, in an exercise to translate 'Protestant' natural law for use in Catholic Italy, but also as an argumentative authority in different Italian contexts.

Finally, Victor Simon shows how diplomatic vocabularies entered legal discourse, emphasising sovereign authority and particularly the legal consequences which derived from the titles used in diplomatic practice to designate the King of France. While the dragomans attached to the French embassy succeeded to introduce the term parsihah ('ruler of the rulers') in bilateral documents, French diplomats managed to have their sovereign recognised as preeminent above other European rulers.

This focus section aims to illustrate different legal historical approaches and narratives on the history of international law in the eighteenth century, 
scrutinizing the relevance and importance of sources produced by and on diplomats and diplomacy for the development of international law. The application, adaptation, circulation and transformation of law of nations theory are inextricably linked to these mechanisms. At the same time, legal discourse, legal reasoning and legal vocabulary were strongly influenced by practice, which characterised the modern idea of diplomacy and international law, with its own peculiarities.

The life of international law was at the heart of seminal classics such as Vattel's Le droit des gens or the right of intervention enshrined in the Peace of Westphalia. This corpus of the 'classical law of nations', ${ }^{7}$ in itself broader than doctrine alone, was the source for nineteenth century doctrine of so-called 'positivist' law of nations. Klüber, Martens, von Holtzendorff, Wheaton and Schmalz built on the established principles of interactions between states. Whether one reads these works on sovereignty and recognition, on the management of the European Balance or on diplomatic immunities, the shadow of the eighteenth century is unavoidable. ${ }^{8}$

Until recently, scholarship in legal history has focused on the 'school of natural law', its theoretical pedigree (Grotius, Gentili) ${ }^{9}$ and the later invocation, interpretation and adaptation of its authors (Pufendorf, Wolff, Vattel). ${ }^{10}$ The present focus section serves to remind us of the distinct nature of doctrine in training the actors of diplomacy, giving rise to new practice, in the framework of a European circulation of ideas. Adapting to Enlightenment or to the rise of

Lesaffer, Randall. 'The Classical Law of Nations (1500-1800)', in Research Handbook on the Theory and History of International Law, ed. Alexander Orakhelashvili (Cheltenham: E. Elgar, 2011), 408-440, DOI 10.4337/9780857933089.

Vec, Miloš. 'Sources of International Law in the Nineteenth-Century European Tradition: The Myth of Positivism', in The Oxford Handbook of the Sources of International Law, eds. Samantha Besson and Jean d'Aspremont (Oxford: oup, 2017), 19-36, DOI 10.1093/ law/9780198745365.003.00o6.

$9 \quad$ Kingsbury, Benedict and Benjamin Straumann, eds. The Roman Foundations of the Law of Nations. Alberico Gentili and the Justice of Empire (Oxford: OUP, 2010), DOI 10.1093/acprof: oso/9780199599875.001.0oo1; Zurbuchen, Simone, ed. The Law of Nations and Natural Law 1625-180o (Leiden/Boston: Martinus Nijhoff/Brill, 2019).

10 Haara, Heikki. Pufendorf's Theory of Sociability: Passions, Habits and Social Order (Heidelberg: Springer, 2018), DoI 10.1007/978-3-319-99325-6; Kadelbach, Stefan, Thomas Kleinlein and David Roth-Isigkeit, eds. System, Order and International Law. The Early History of International Legal Thought from Machiavelli to Hegel (Oxford: OUP, 2017), DOI 10.1093/acprof:oso/9780198768586.oo1.ooo1; Rech, Walter. Enemies of Mankind. Vattel's Theory of Collective Security (Leiden/Boston: Martinus Nijhoff/Brill, 2013), DOI 10.1163/978900425435o; Stapelbroek, Koen and Antonio Trampus, eds. The Legacy of Vattel's Droit des Gens (Basingstoke: Palgrave MacMillan/Springer, 2019). 
national sovereignty, the eighteenth century law of nations was an eminently flexible framework, allowing for a rich grid of interpretation, at the crossroads of preceding and new intellectual traditions, but foremost embedded in a fascinating material and political context.

\section{Bibliography}

Andretta, Stefano, Stéphane Péquignot and Jean-Claude Waquet, eds. De l'ambassadeur et à l'art de négocier du Moyen Âge au début du XIX ${ }^{e}$ siècle (Rome: École française de Rome, 2015).

Bourdieu, Pierre. Sur l'Etat. Cours au Collège de France (1989-1992) (Paris: Seuil, 2012).

Drocourt, Nicolas and Éric Schnakenbourg, eds. Thémis en diplomatie: l'argument juridique dans les relations internationales de l'antiquité tardive à la fin du XVIII siècle (Rennes: Presses universitaires de Rennes, 2016).

Haara, Heikki. Pufendorf's Theory of Sociability: Passions, Habits and Social Order (Heidelberg: Springer, 2018).

Haggenmacher, Peter and Vincent Chetail, eds. Vattel's International Law from a XXIst Century Perspective (Leiden/Boston: Martinus Nijhoff/Brill, 2011).

Kadelbach, Stefan, Thomas Kleinlein and David Roth-Isigkeit, eds. System, Order and International Law. The Early History of International Legal Thought from Machiavelli to Hegel (Oxford: OuP, 2017).

Kingsbury, Benedict and Benjamin Straumann, eds. The Roman Foundations of the Law of Nations. Alberico Gentili and the Justice of Empire (Oxford: oup, 2010).

Lesaffer, Randall. 'The Classical Law of Nations (1500-180o)', in Research Handbook on the Theory and History of International Law, ed. Alexander Orakhelashvili (Cheltenham: E. Elgar, 2011), 408-440.

Nuzzo, Luigi and Miloš Vec, eds. Constructing International Law - The Birth of a Discipline (Frankfurt am Main: V. Klostermann, 2012).

Rech, Walter. Enemies of Mankind. Vattel's Theory of Collective Security (Leiden/Boston: Martinus Nijhoff/Brill, 2013).

Stapelbroek, Koen and Antonio Trampus, eds. The Legacy of Vattel's Droit des Gens (Basingstoke: Palgrave MacMillan/Springer, 2019).

Vec, Miloš. 'Sources of International Law in the Nineteenth-Century European Tradition: The Myth of Positivism, in The Oxford Handbook of the Sources of International Law, eds. Samantha Besson and Jean d'Aspremont (Oxford: oup, 2017), 19-36.

Zurbuchen, Simone, ed. The Law of Nations and Natural Law 1625-1800 (Leiden/Boston: Martinus Nijhoff/Brill, 2019). 